\title{
Effects of 2000-2050 Global Change on Ozone Air Quality in the United States
}

\section{Citation}

Wu, Shiliang, Loretta J. Mickley, Eric M. Leibensperger, Daniel J. Jacob, David Rind and David G. Streets. 2008. Effects of 2000-2050 global change on ozone air quality in the United States. Journal of Geophysical Research 113(D06302): 1-12.

\section{Published Version}

doi:10.1029/2007JD008917

\section{Permanent link}

http://nrs.harvard.edu/urn-3:HUL.InstRepos:3554392

\section{Terms of Use}

This article was downloaded from Harvard University's DASH repository, and is made available under the terms and conditions applicable to Other Posted Material, as set forth at http:// nrs.harvard.edu/urn-3:HUL.InstRepos:dash.current.terms-of-use\#LAA

\section{Share Your Story}

The Harvard community has made this article openly available.

Please share how this access benefits you. Submit a story.

\section{Accessibility}




\title{
Effects of 2000-2050 global change on ozone air quality in the United States
}

\author{
Shiliang Wu, ${ }^{1}$ Loretta J. Mickley, ${ }^{1}$ Eric M. Leibensperger, ${ }^{1}$ Daniel J. Jacob, ${ }^{1}$ David Rind, ${ }^{2}$ \\ and David G. Streets ${ }^{3}$ \\ Received 4 May 2007; revised 9 October 2007; accepted 26 November 2007; published 19 March 2008.
}

[1] We investigate the effects on U.S. ozone air quality from 2000-2050 global changes in climate and anthropogenic emissions of ozone precursors by using a global chemical transport model (GEOS-Chem) driven by meteorological fields from the NASA Goddard Institute for Space Studies general circulation model (NASA/GISS GCM). We follow the Intergovernmental Panel on Climate Change A1B scenario and separate the effects from changes in climate and anthropogenic emissions through sensitivity simulations. The 2000-2050 changes in anthropogenic emissions reduce the U.S. summer daily maximum 8 -hour ozone by $2-15 \mathrm{ppb}$, but climate change causes a $2-5 \mathrm{ppb}$ positive offset over the Midwest and northeastern United States, partly driven by decreased ventilation from convection and frontal passages. Ozone pollution episodes are far more affected by climate change than mean values, with effects exceeding $10 \mathrm{ppb}$ in the Midwest and northeast. We find that ozone air quality in the southeast is insensitive to climate change, reflecting compensating effects from changes in isoprene emission and air pollution meteorology. We define a "climate change penalty" as the additional emission controls necessary to meet a given ozone air quality target. We find that a $50 \%$ reduction in U.S. $\mathrm{NO}_{\mathrm{x}}$ emissions is needed in the 2050 climate to reach the same target in the Midwest as a $40 \%$ reduction in the 2000 climate. Emission controls reduce the magnitude of this climate change penalty and can even turn it into a climate benefit in some regions.

Citation: Wu, S., L. J. Mickley, E. M. Leibensperger, D. J. Jacob, D. Rind, and D. G. Streets (2008), Effects of 2000-2050 global change on ozone air quality in the United States, J. Geophys. Res., 113, D06302, doi:10.1029/2007JD008917.

\section{Introduction}

[2] Ozone in surface air is toxic to humans and vegetation. It is produced by photochemical oxidation of carbon monoxide and volatile organic compounds (VOCs) in the presence of nitrogen oxides $\left(\mathrm{NO}_{\mathrm{x}} \equiv \mathrm{NO}+\mathrm{NO}_{2}\right)$. These ozone precursors have large anthropogenic emissions, particularly from fuel use. Rapid global change, including changes in both climate and anthropogenic emissions of ozone precursors, is expected in the coming decades [Intergovernmental Panel on Climate Change (IPCC), 2001, 2007]. These changes have consequences for future ozone air quality by affecting air pollution meteorology [Holzer and Boer, 2001; Rind et al., 2001; Mickley et al., 2004; Leung and Gustafson, 2005] as well as ozone production on regional and global scales [Jacob et al., 1999; Fiore et al., 2002a, 2002b; Hogrefe et al., 2004; Stevenson et al., 2005, 2006; Murazaki and Hess, 2006; Tagaris et al., 2007].

\footnotetext{
${ }^{1}$ School of Engineering and Applied Sciences, Harvard University, Cambridge, Massachusetts, USA. USA.

${ }^{2}$ NASA Goddard Institute for Space Studies, New York, New York,

${ }^{3}$ Argonne National Laboratory, Argonne, Illinois, USA.

Copyright 2008 by the American Geophysical Union. 0148-0227/08/2007JD008917\$09.00
}

[3] Decadal projections of changes in global emissions of greenhouse gases, aerosols, and ozone precursors have been developed by the IPCC for four socioeconomic scenarios for the 21 st century (A1, A2, B1, B2) [Nakicenovic and Stewart, 2000]. The A1 scenario further distinguishes three subscenarios (A1FI, A1T, A1B) by technological emphasis. These scenarios have been extensively applied for climate change projections using general circulation models (GCMs). All scenarios project a global increase of anthropogenic emissions of ozone precursors for 2000-2050, largely driven by economic growth in developing countries, but three of them (A1B, A1T, B1) project decreasing emissions in OECD countries including the United States. Dentener et al. [2005] suggest that future emission growth in developing countries may be lower than projected by the IPCC [2001] because air pollution control legislation will likely become stronger.

[4] Climate change can influence surface ozone air quality by affecting the regional-scale air pollution meteorology as well as the chemical environment for ozone formation. Lin et al. [2001] showed that the probability of ozone air quality standard exceedances in different regions of the United States correlates strongly with temperature, suggesting that a rise in temperature would aggravate ozone pollution. A model sensitivity study by Dawson et al. [2007] indicates that a uniform increase of surface temper- 
Table 1a. The 2000-2050 Trends in Anthropogenic Emissions of Ozone Precursors ${ }^{\mathrm{a}}$

\begin{tabular}{|c|c|c|c|c|c|c|}
\hline \multirow[b]{2}{*}{ Species } & \multicolumn{3}{|c|}{ World } & \multicolumn{3}{|c|}{ Contiguous United States } \\
\hline & $2000^{\mathrm{b}}$ & 2050 & Change, $\%$ & $2000^{\mathrm{b}}$ & 2050 & Change, $\%$ \\
\hline \multicolumn{7}{|c|}{$N O_{x}, T g N a^{-1}$} \\
\hline Fossil fuel combustion & 24.6 & 47.3 & +92 & 5.9 & 3.6 & -40 \\
\hline Biomass burning & 6.5 & 8.1 & +25 & 0.03 & 0.06 & +100 \\
\hline Biofuel & 2.2 & 2.1 & -5 & 0.01 & 0.01 & 0 \\
\hline Fertilizer & 0.5 & 0.9 & +80 & 0.05 & 0.06 & +8 \\
\hline \multicolumn{7}{|c|}{$C O, \operatorname{TgCO} a^{-1}$} \\
\hline Fossil fuel combustion & 381 & 363 & -5 & 81 & 35 & -57 \\
\hline Biomass burning & 459 & 750 & +63 & 3.4 & 8.4 & +150 \\
\hline Biofuel & 176 & 169 & -4 & 3 & 2.6 & -13 \\
\hline \multicolumn{7}{|c|}{ NMVOCs, ${ }^{\mathrm{c}} \mathrm{Tg} C \mathrm{a}^{-1}$} \\
\hline Anthropogenic emissions & 43 & 98 & +130 & 9.3 & 4.4 & -52 \\
\hline Biomass burning & 10 & 17 & +66 & 0.09 & 0.21 & +133 \\
\hline Methane, ppb & 1750 & 2400 & +37 & & & \\
\hline
\end{tabular}

${ }^{\mathrm{a}}$ Based on the IPCC [2001] A1B scenario.

${ }^{\mathrm{b}}$ The base year used for present-day anthropogenic emission inventories is 1999 for the United States and 1995 elsewhere.

${ }^{\mathrm{c}}$ Nonmethane VOCs including alkanes, alkenes, and acetone.

ature by $2.5 \mathrm{~K}$ would result in $1-3 \mathrm{ppb}$ increases of the summertime daily maximum 8-hour average ozone in the east. Mickley et al. [2004] showed that the severity and duration of summertime stagnation episodes in the Midwest and northeast could increase significantly in the 2050s climate relative to present owing to decline in the frequency of midlatitude cyclones tracking across southern Canada. Decreasing cyclone frequency as a result of greenhouse warming appears to be a robust result from both model studies [Lambert and Fyfe, 2006] and long-term observations [McCabe et al., 2001].

[5] A number of previous chemical transport model (CTM) studies driven by general circulation models (GCMs) have examined the effect of 21 st century climate change alone on ozone air quality in the United States, assuming no changes in emissions in order to isolate the climate change effect. Hogrefe et al. [2004] applied a regional model to 1990-2050 climate change (A2 scenario), and found a $4.2 \mathrm{ppb}$ mean increase in the summertime daily maximum 8-hour average ozone in the east. Another regional model study by Kunkel et al. [2007] found 2000-2100 increases in daily maximum 8-hour average ozone in the northeast by $10-24 \%$ (A1FI scenario) and $0-10 \%$ (B1 scenario). A global model study by Murazaki and Hess [2006] found an increase of summer ozone of up to $5 \mathrm{ppb}$ in the east by 2100 (A1 scenario) but little change in the west. Another global model study by Racherla and Adams [2006] for 1990-2050 (A2 scenario) found ozone decreases over most of the United States but slight increases over the mid-Atlantic region and a large increase in the southeast.

[6] Other CTM/GCM studies have examined the combined effect on U.S. ozone air quality of 21 st-century changes in climate and in anthropogenic emissions of ozone precursors. Tao et al. [2007] found an increase of U.S. surface ozone by 2050 by $2-15 \%$ with the A1FI scenario and a decrease by $4-12 \%$ with the B1 scenario. Tagaris et al. [2007] calculated decreases of $11-28 \%$ (A1B scenario), largely driven by the projected domestic emission reductions.

[7] We use here a global CTM for tropospheric ozone and aerosols (GEOS-Chem), driven by meteorological fields from the NASA/GISS GCM 3, to investigate the effects of A1B 2000-2050 global change on ozone air quality in the United States. The A1B scenario describes a future world with rapid economic growth and introduction of new and more energy-efficient technologies, reduction in regional differences of per capita income, and balanced energy generation from fossil and alternative fuels. We account for the effects of climate change on natural emissions of ozone precursors, including biogenic VOC emissions from vegetation and $\mathrm{NO}_{\mathrm{x}}$ emissions from lightning and soils. The effects from climate change and from changes in anthropogenic emissions of ozone precursors are studied separately and then together through an ensemble of sensitivity simulations.

\section{Model Description and Future Emissions}

[8] The interface between the GEOS-Chem CTM and the GISS GCM was previously described by Wu et al. [2007].

Table 1b. The 2000-2050 Trends in Natural Emissions of Ozone Precursors ${ }^{\mathrm{a}}$

\begin{tabular}{|c|c|c|c|c|c|c|}
\hline \multirow[b]{2}{*}{ Species } & \multicolumn{3}{|c|}{ World } & \multicolumn{3}{|c|}{ Contiguous United States } \\
\hline & 2000 & 2050 & Change, \% & 2000 & 2050 & Change, $\%$ \\
\hline \multicolumn{7}{|l|}{$\mathrm{NO}_{\mathrm{x}}, \mathrm{Tg} \mathrm{N} \mathrm{a}^{-1}$} \\
\hline Lightning & 4.9 & 5.8 & +18 & 0.14 & 0.17 & +21 \\
\hline Soil & 6.1 & 6.6 & +8 & 0.35 & 0.39 & +11 \\
\hline Isoprene, $\mathrm{Tg} \mathrm{C} \mathrm{a}{ }^{-1}$ & 430 & 540 & +25 & 28 & 35 & +25 \\
\hline Other biogenic NMVOCs, ${ }^{\mathrm{b}} \mathrm{Tg} \mathrm{C} \mathrm{a}{ }^{-1}$ & 180 & 210 & +20 & 12 & 14 & +20 \\
\hline
\end{tabular}

${ }^{a}$ Results are based on 3-year general circulation model averages (1999-2001 and 2049-2051).

${ }^{\mathrm{b}}$ Including alkenes, monoterpenes, and acetone, but not methanol. 


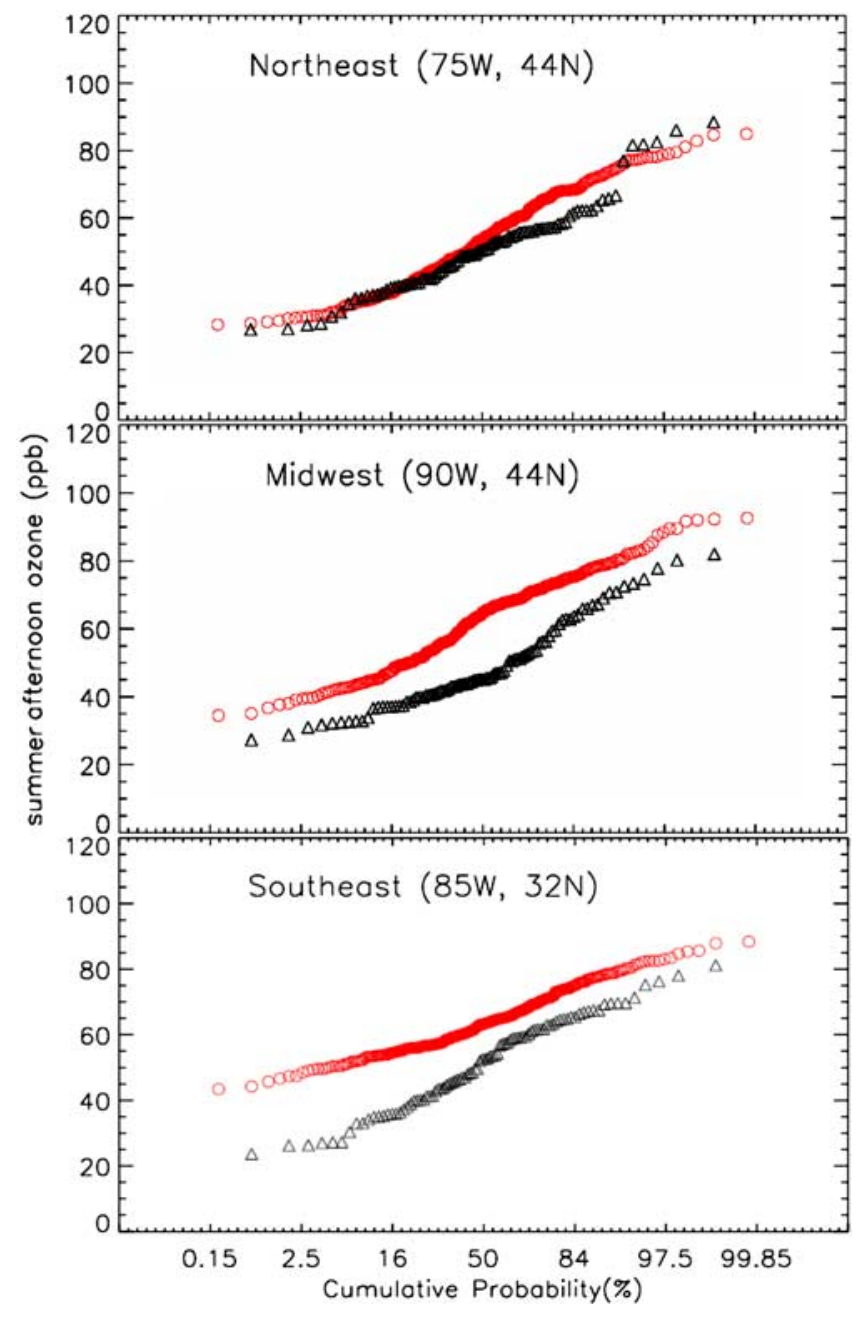

Figure 1. Cumulative probability distributions of summer (June-August) afternoon (1300-1700 local time) surface $\mathrm{O}_{3}$ concentrations over $4^{\circ} \times 5^{\circ}$ grid squares centered in the northeast, Midwest, and southeast at $(75 \mathrm{~W}, 44 \mathrm{~N})$, $(90 \mathrm{~W}, 44 \mathrm{~N})$, and $(115 \mathrm{~W}, 36 \mathrm{~N})$, respectively. Red circles are model results from three summers of the present-day climate (1999-2001). Black triangles are observations for 1995 averaged over the $4^{\circ} \times 5^{\circ}$ model grid as compiled by Fiore et al. [2002b].

We use the "qflux" version of the GISS GCM 3, with a horizontal resolution of $4^{\circ}$ latitude by $5^{\circ}$ longitude and 23 vertical layers in a sigma-pressure coordinate system extending from the surface to $0.002 \mathrm{hPa}$ [Hansen et al., 1984, 1988; Rind et al., 2008]. The lowest three layers extend up to 200,500 , and $1000 \mathrm{~m}$ altitude for a column based at sea level. In the qflux model, monthly mean ocean heat transport fluxes are calculated iteratively for presentday climate to reproduce observed sea surface temperatures. These ocean heat transport fluxes are then held fixed, while sea surface temperatures and ocean ice are permitted to respond to changes in climate. We performed a 1950-2000 spin-up starting from climate equilibrium to adequately initialize the ocean, using observed trends of the well-mixed greenhouse gases (including $\mathrm{CO}_{2}, \mathrm{CH}_{4}, \mathrm{~N}_{2} \mathrm{O}$, and halocarbons), ozone, and aerosols [Hansen et al., 2002]. For 2001 to 2050 we followed the IPCC A1B scenario for the wellmixed greenhouse gases, with $\mathrm{CO}_{2}$ as calculated in the Bern-CC model [Houghton et al., 2001]. $\mathrm{CO}_{2}$ levels reach $522 \mathrm{ppm}$ by 2050 . We assumed no changes in ozone and aerosol concentrations during 2001-2050 for the purpose of driving climate change.

[9] Meteorological output from the GISS GCM was archived with 6-hour resolution (3-hour for surface quantities and mixing depths) for input to the GEOS-Chem CTM, replicating the type and frequency of input variables customarily provided to GEOS-Chem by the NASA/Goddard Earth Observing System (GEOS) assimilated meteorological observations [Bey et al., 2001]. The GEOS-Chem spatial resolution used here follows that of the GISS GCM. We use GEOS-Chem version 7.03.06 ( http://www.as.harvard.edu/ chemistry/trop/geos/) to simulate tropospheric ozone- $\mathrm{NO}_{\mathrm{x}}$ VOC-aerosol chemistry [Park et al., 2004].

[10] The base year used for present-day anthropogenic emission inventories is 1999 for the United States and 1995 elsewhere (Table 1a). We use 2050 estimates of anthropogenic emissions of ozone and aerosol precursors from the IPCC A1B scenario as interpreted by the Integrated Model to Assess the Greenhouse Effect (IMAGE) socioeconomic model [Streets et al., 2004] (Table 1a). Similarly to Fiore et al. [2002a], we derive 2000-2050 growth factors for different categories of anthropogenic emissions (fossil fuel, biofuel, and biomass burning) and for different countries, and then apply these factors to the present-day GEOS-Chem emission inventories. Biomass burning is further separated into contributions from forest fires, grassland fires, and infield crop burning. Trends in ship and aircraft emissions are not considered. Fossil fuel $\mathrm{NO}_{\mathrm{x}}$ emissions rise by $90 \%$ globally over the $2000-2050$ period but decrease by $40 \%$ in the United States (Table 1a). For simulations with presentday anthropogenic emissions, the methane concentrations are specified with a global mean of $1750 \mathrm{ppb}$ and a $5 \%$ interhemispheric gradient based on observations. Methane is projected to rise to $2400 \mathrm{ppb}$ by 2050 in the A1B scenario [IPCC, 2001], and a globally uniform methane concentration of $2400 \mathrm{ppb}$ is included in the model chemistry for the simulations with future anthropogenic emissions.

[11] Natural emissions of ozone precursors (Table 1b) including nonmethane VOCs (NMVOCs) from vegetation, and $\mathrm{NO}_{\mathrm{x}}$ from lightning and soil, are computed locally within the model on the basis of meteorological variables and hence allowed to change in response to climate change. Biogenic emissions of NMVOCs are influenced solely by temperature and solar radiation [Guenther et al., 1995; Wang et al., 1998]; we do not account for the effects of changes in atmospheric $\mathrm{CO}_{2}$ concentrations [Constable et al., 1999; Rosenstiel et al., 2003; Centritto et al., 2004] or land cover [Sanderson et al., 2003]. Lightning $\mathrm{NO}_{\mathrm{x}}$ emissions are parameterized as a function of deep convective cloud top [Price and Rind, 1992; Wang et al., 1998; Li et al., 2005] and are distributed vertically following Pickering et al. [1998]. We do not account for possible 2000-2050 changes in stratosphere-troposphere exchange (STE) of ozone. In all simulations, STE for ozone is represented by the Synoz flux boundary condition [McLinden et al., 2000] with an imposed global annual mean STE flux of $500 \mathrm{Tg} \mathrm{a}^{-1}$. Effects of climate change on biomass burning are not considered in this study. 

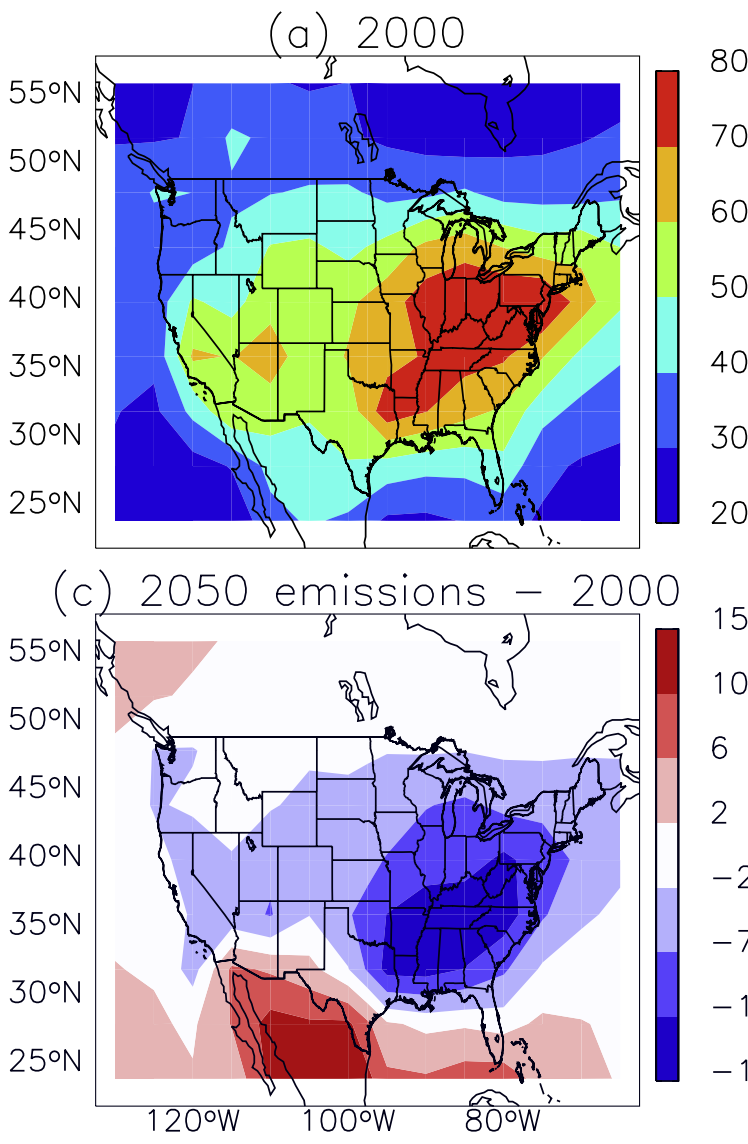
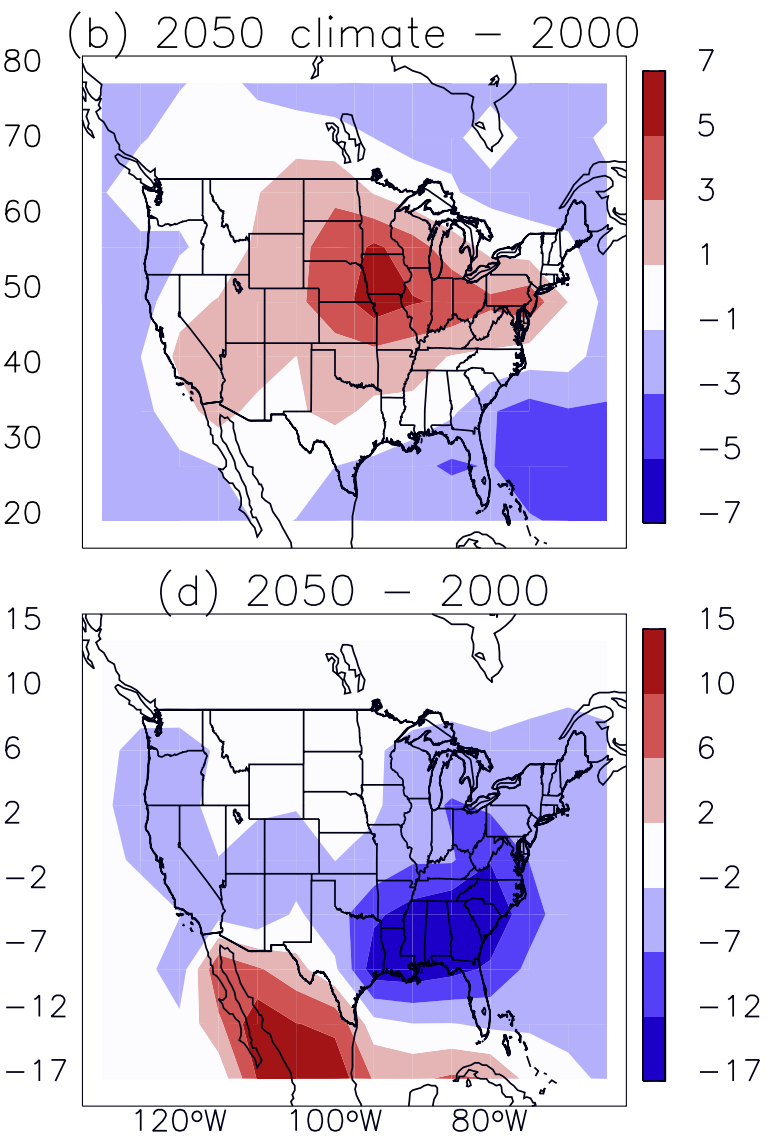

Figure 2. Simulated mean daily maximum 8-hour average surface ozone (ppb) in summer (JuneAugust) for (a) 2000 conditions and perturbations from 2050 changes in (b) climate, (c) anthropogenic emissions of ozone precursors, and (d) both climate and anthropogenic emissions. Note the difference in scales between panels.

[12] The GISS GCM yields a global mean surface temperature increase of $1.6 \mathrm{~K}$ for 2000-2050. Summertime temperatures increase by as much as $2-3 \mathrm{~K}$ over the United States. The annual mean precipitation increases by $8 \%$ globally; it increases by up to $20 \%$ over large areas in the United States, including in the east, but decreases by up to $20 \%$ along the Pacific coast and in Texas. The biogenic emission of isoprene in the United States increases by $25 \%$ in the future climate owing to higher temperature (Table 1b). Global lightning $\mathrm{NO}_{\mathrm{x}}$ emission increases by $18 \%$ owing to deeper convection, and soil $\mathrm{NO}_{\mathrm{x}}$ emission increases by $8 \%$ owing to increased temperature and precipitation.

[13] We conducted simulations for four cases: (1) presentday climate and emissions, (2) 2050 climate and present-day anthropogenic emissions of ozone and aerosol precursors, (3) present-day climate and 2050 anthropogenic emissions of ozone and aerosol precursors, and (4) 2050 climate and emissions. Each case was run for 3 years (1999-2001 or 2049-2051) following 1 year of model spin-up. Unless noted otherwise, all the results discussed in this paper are 3 -year averages. Examination of the 2000-2050 time series of GISS meteorological data fields indicates that 3-year samples are sufficient to characterize changes in the 2050 versus 2000 climate. Wu et al. [2007] showed that the corresponding interannual variability in tropospheric ozone budgets simulated by GEOS-Chem is weak ( $1 \%$ for global ozone burden and $0.2 \%$ for global ozone production).

\section{Model Evaluation}

[14] The GEOS-Chem model driven by assimilated GEOS meteorological fields has been extensively evaluated in past studies by comparisons with observations of ozone and its precursors, both globally [e.g., Bey et al., 2001; Martin et al., 2002; Sauvage et al., 2007] and more specifically for the United States [e.g., Fiore et al., 2002b, 2003a, 2003b; Hudman et al., 2004, 2007; Li et al., 2002a, 2002b, 2004, 2005] (see also R. C. Hudman et al., North American influence on tropospheric ozone and the effects of recent emission reductions: Constraints from ICARTT aircraft observations, manuscript in preparation, 2007; hereinafter referred to as Hudman et al., manuscript in preparation, 2007). Fiore et al. [2003b] showed by comparison with higher-resolution GEOS-Chem and regional model simulations that the $4^{\circ} \times 5^{\circ}$ resolution does not induce significant mean bias for surface ozone and can still capture major synoptic forcings of air pollution meteorology, although the ability to capture local ozone maxima is of course compromised.

[15] Wu et al. [2007] presented a general evaluation of the GISS-driven GEOS-Chem simulation for ozone and its 
(a) Temperature $(2050$ - 2000)

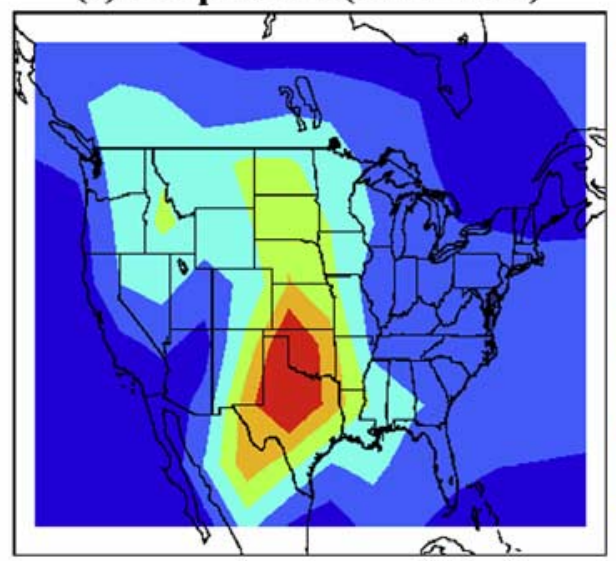

(c) Soil moisture $(2050 / 2000)$

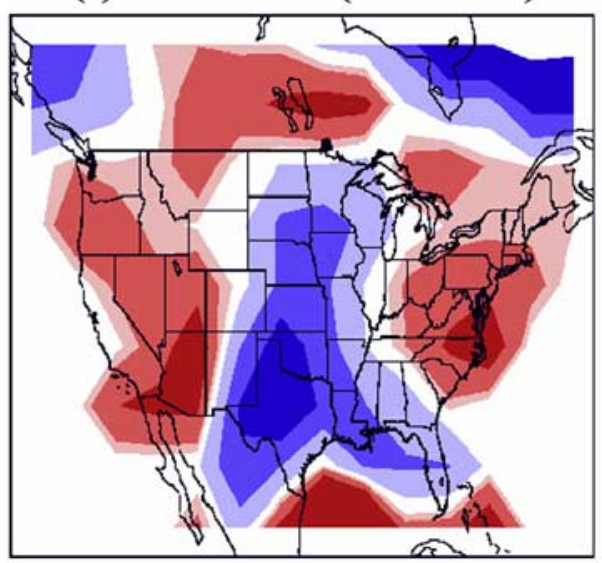

(b) Mixing depth $(2050 / 2000)$

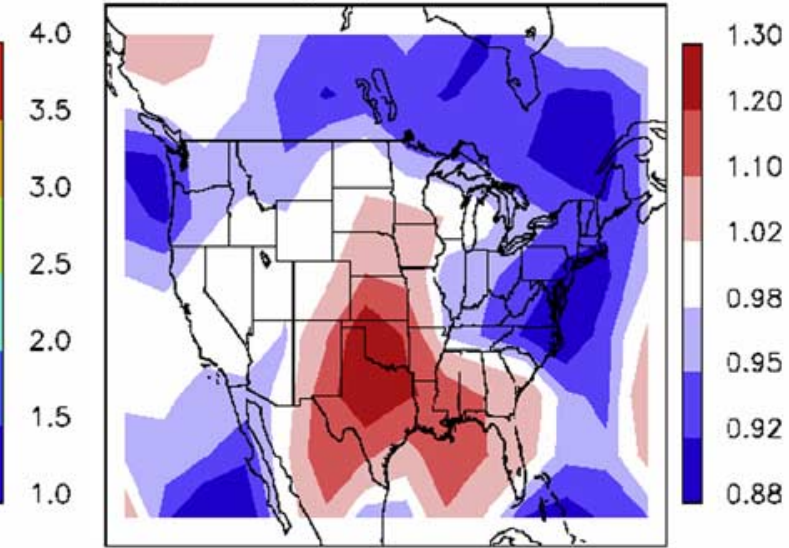

(d) $850 \mathrm{hPa}$ wet convective mass flux (2050-2000)

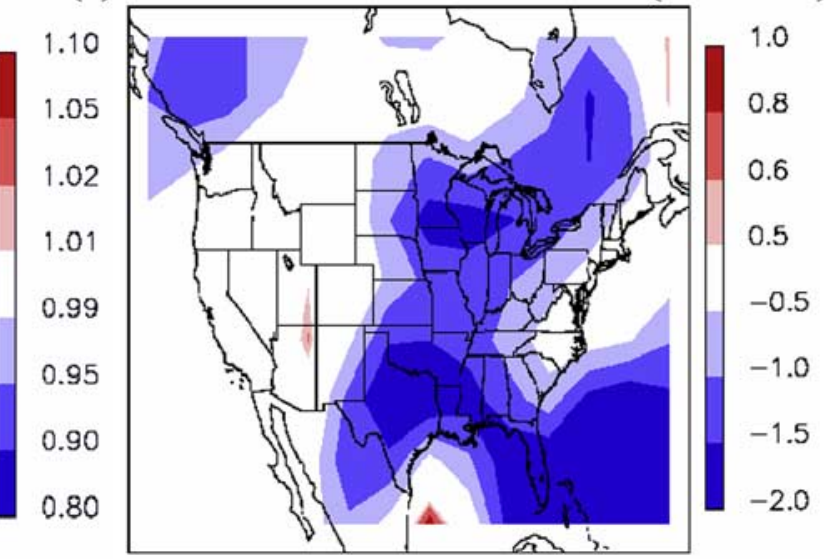

Figure 3. Simulated 2000-2050 changes in summertime air pollution meteorology over the United States: (a) differences in surface air temperature in K, (b) ratios of afternoon (1200-1600 local time) mixing depth, (c) ratios of soil moisture, and (d) differences in $850 \mathrm{hPa}$ wet convective mass flux in units of $10^{-3} \mathrm{~kg} \mathrm{~m}^{-2} \mathrm{~s}^{-1}$. Values are 3-month means for June-August 2049-2051 versus 1999-2001.

precursors by comparison with climatological ozonesonde data and with GEOS-driven simulations. Global budgets and distributions of tropospheric ozone and its precursors show in general excellent agreement. The model reproduces the observed ozonesonde climatology usually to within 10 $\mathrm{ppb}$ throughout the troposphere.

[16] We present here a more focused evaluation of the ability of the GISS-driven model to simulate ozone pollution episodes in the United States by comparison with observed probability distributions, following a similar evaluation conducted by Fiore et al. [2002b] for the GEOSdriven model for 1995. The year of 1995 was characterized by relatively high ozone concentrations [Lin et al., 2001]. Figure 1 shows the cumulative probability distributions of summer (June-August) afternoon (1300-1700 local time) ozone concentrations in surface air for three representative $4^{\circ} \times 5^{\circ}$ model grid squares. The model results for three years of the present-day climate are compared with 1995 spatial averages of data for the ensemble of ozone surface sites located in the corresponding model grid square, as compiled by Fiore et al. [2002b].

[17] We can see from Figure 1 that the model reproduces well the observed probability distribution of ozone over the northeast, including the range of variability and the high tail of the distribution (pollution episodes). The model overestimates surface ozone by up to $10 \mathrm{ppb}$ in the Midwest but again has the correct range of variability. No bias is found in the Midwest when GEOS-Chem is driven by assimilated meteorological data [Fiore et al., 2002b; Hudman et al., manuscript in preparation, 2007], and we attribute the problem here to relatively weak surface winds in the GISS GCM. Over the southeast, the model overestimates the lower tail of the distribution, a problem previously pointed out by Fiore et al. [2002b] in the GEOS-driven simulation and which appears to be due to excessive ozone in inflow from the Gulf of Mexico. Overall, and despite some positive mean bias of up to $10 \mathrm{ppb}$ in some regions, we see that the model can reproduce the summertime temporal variability of ozone concentrations leading to pollution episodes.

\section{Effect of Global Change on U.S. Ozone Air Quality}

4.1. Effect on Daily Maximum Ozone Concentrations

[18] The U.S. EPA has been using the metric of daily maximum 8-hour average ozone for the ozone air quality 


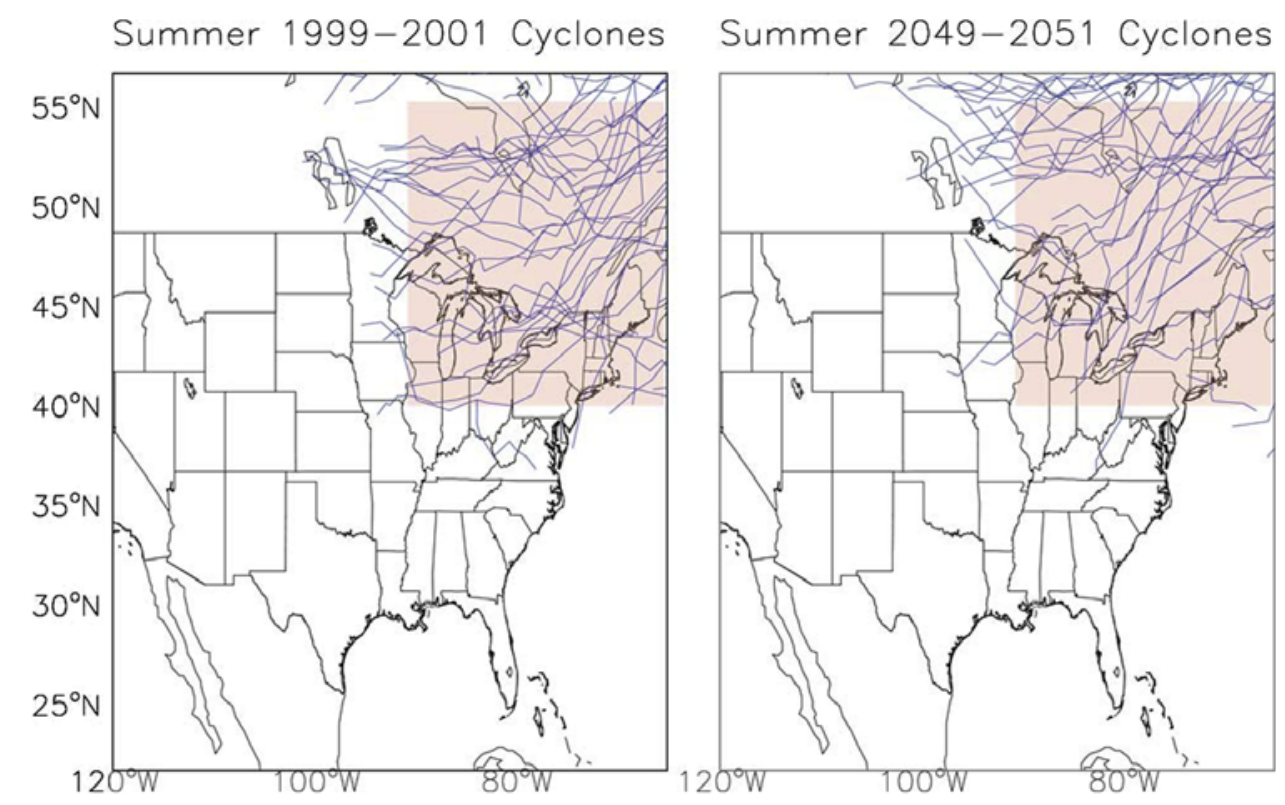

Figure 4. Cyclone tracks for June-August of 1999-2001 and 2049-2051. Cyclone tracks were identified by sea level pressure minima at least $720 \mathrm{~km}$ in radius propagating for at least 24 hours at no more than $120 \mathrm{~km} \mathrm{~h}^{-1}$ (Chandler and Jonas, 1999). The number of cyclones was counted over the shaded area bound by $40^{\circ}-55^{\circ} \mathrm{N}$ and $60^{\circ}-90^{\circ} \mathrm{W}$ (see section 4.1 for discussion).

standard. We use this metric here and focus our attention on the summer months (June-August) when ozone is highest. Figure 2 shows the simulated daily maximum 8-hour average surface ozone concentrations averaged over June-August for 2000 conditions, and the perturbations from 2000-2050 changes in climate and anthropogenic emissions separately and then together.

[19] The effect of 2000-2050 changes in anthropogenic emissions alone is to reduce the summer daily maximum 8-hour average ozone by $1-5 \mathrm{ppb}$ in the west and 5$15 \mathrm{ppb}$ in the east. These decreases reflect the projected emission reductions in the United States (Table 1a). However, they can be partly offset by climate change. When only climate change is considered and the anthropogenic emissions of ozone precursors are held at present-day levels, the daily maximum 8 -hour average ozone increases by $2-5 \mathrm{ppb}$ over large areas in the United States, with maximum effect over the central states (Figure 2). In contrast, the ozone background as represented by the ozone concentrations over the oceans decreases with climate change, largely driven by the decrease of ozone lifetime associated with higher water vapor [Johnson et al., 1999]. The shorter lifetime of PAN in a warmer climate also contributes to the decrease of ozone levels in remote areas while it can increase the ozone levels near source regions. Negligible effects of climate change on ozone or slight decreases are found over the northwest, southeast, and New England; this partly reflects the decrease in the ozone background, although the trend in the southeast is more complicated as discussed below.

[20] Important regional meteorological variables affecting ozone pollution in the United States include temperature, mixing depth, convective ventilation, and cyclone frequency. Figure 3 shows the simulated 2000-2050 mean summertime changes in the first three variables and soil moisture. Temperatures increase by $1-2{ }^{\circ} \mathrm{C}$ in the east and $2-3{ }^{\circ} \mathrm{C}$ in the west. Warming is greatest over Texas owing to a northeastward shift of the Bermuda High that reduces the influx of cool air and moisture from the Gulf of Mexico. This shift of the Bermuda High is an expected result of global warming [Lu et al., 2007]. The drying of Texas also results in a large regional increase in mixing depth, whereas mixing depths tend to decrease in the rest of the country owing to increased soil moisture.

[21] Wet convective mass fluxes tend to decrease in the east, as shown in Figure 3. In general, increased water evaporation from the oceans in the future climate is expected to increase stability over continents owing to latent heat release [Rind, 1986]. However, we also find an increase in the frequency of deep convection, reflected in the increase in lightning $\mathrm{NO}_{\mathrm{x}}$ emissions (Table 1b). Convective plumes, although generally less frequent in the future climate, can reach higher altitude owing to more available water vapor [Del Genio et al., 2007].

[22] Figure 4 shows the summertime cyclone tracks over North America for the 2050 versus 2000 climate. We tracked individual cyclones using the 6-hour GCM sea level pressure fields and the cyclone tracking method of M. Chandler and J. Jonas (Atlas of extratropical storm tracks (1961-1998), NASA Goddard Institute for Space Studies, 1999. Available at http://www.giss.nasa.gov/data/ stormtracks; hereinafter referred to as Chandler and Jonas, 1999). We find a $17 \%$ decrease in the number of cyclones passing over southeastern Canada (bound by $40^{\circ}-55^{\circ} \mathrm{N}$ and $60^{\circ}-90^{\circ} \mathrm{W}$ ), where cyclonic passages are most relevant for ventilating the central and eastern United States. Within this southeastern Canada region the mean latitude of the cyclone tracks shifts northward from $45^{\circ} \mathrm{N}$ to $49^{\circ} \mathrm{N}$, likely resulting in less efficient U.S. ventilation. This is consistent with 


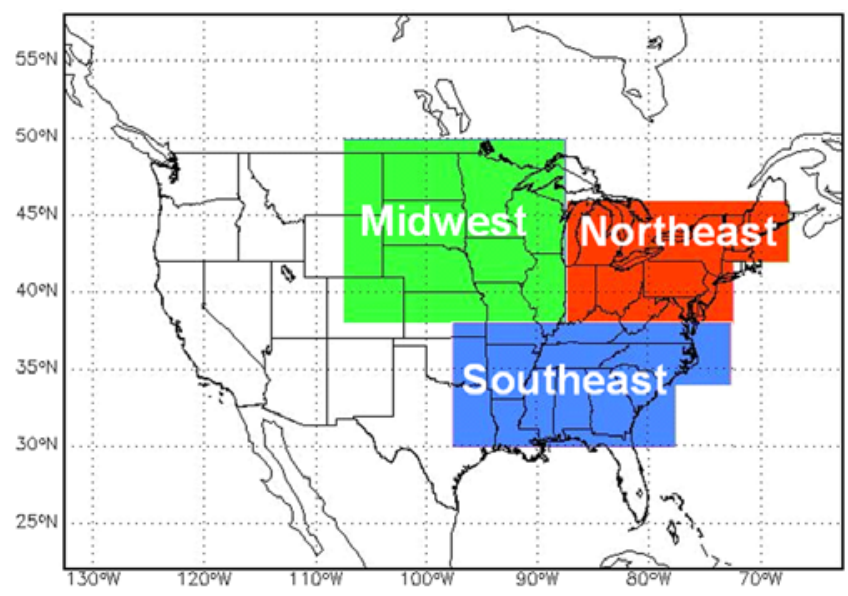

Figure 5. Geographical definition of the northeast, Midwest, and southeast regions used in section 4.2 and in Figures 6-8.

previous 2000-2050 climate change simulations by Mickley et al. [2004] who, using the GISS GCM 2' and 8-year ensembles, found an increase in the frequency of stagnation episodes in the eastern United States in the 2050 climate owing to a reduced frequency of northern midlatitude cyclones and associated cold fronts. Murazaki and Hess [2006] also found weaker and less frequent frontal passages in their simulations of future climate using a different GCM.

[23] The 2000-2050 climate-driven ozone increase in the central and northeastern United States in our simulation thus appears to reflect a combination of higher temperatures, lower mixing depths, reduced convective ventilation, and more frequent stagnation episodes. The effect of higher temperatures on ozone is partly through increased emission of biogenic isoprene and partly through lower PAN stability [Jacob et al., 1993; Sillman and Samson, 1995; Dawson et al., 2007].

[24] We find little climate-driven ozone change in the southeast, in contrast to the northeast. Increasing isoprene emission in the southeast in the model actually tends to reduce ozone levels because of (1) sequestration of $\mathrm{NO}_{\mathrm{x}}$ as isoprene nitrates [Wu et al., 2007], and (2) direct ozonolysis of isoprene [Fiore et al., 2005]. A sensitivity simulation for 2000 conditions with $25 \%$ increase in isoprene emissions shows a 1-2 ppb ozone reduction in the southeast in contrast to an increase in the northeast, consistent with the previous work of Fiore et al. [2005]. This result is highly sensitive to whether isoprene nitrates represent a terminal or temporary sink for $\mathrm{NO}_{\mathrm{x}}$ [Wu et al., 2007; Horowitz et al., 2007]. Here, as in the work of Wu et al. [2007], they represent a terminal sink, which seems chemically more likely [Giacopelli et al., 2005].

[25] Previous model studies of the effects on climate change on U.S. ozone air quality concur that future climate change will degrade ozone air quality in the northeast [Hogrefe et al., 2004; Murazaki and Hess, 2006; Racherla and Adams, 2006; Tagaris et al., 2007; Kunkel et al., 2007]. Most of these studies also show degradation of ozone air quality in the Midwest, although Tagaris et al. [2007] find an improvement owing to a simulated increase in cloud cover [Leung and Gustafson, 2005].

[26] The southeast is the region with the least consensus among studies. Hogrefe et al. [2004] found an increase of summertime ozone concentrations in the 2050s but a decrease in the 2080s relative to the 1990s; Racherla and Adams [2006] found the southeast to be the U.S. region with the largest ozone increase in response to 1990-2050 climate change; Murazaki and Hess [2006] also found relatively large ozone increases in the southeast; while the other studies referenced above (including our own) found little effect. All studies except Murazaki and Hess [2006] included increasing isoprene emission from climate change, and we speculate that different treatments of isoprene nitrate chemistry could be a major cause of discrepancies between models. For example, Racherla and Adams [2006] did not include formation of isoprene nitrates in their chemical mechanism (implicitly assuming that they are unstable). The observational analysis by Lin et al. [2001] shows that the probability of daily maximum 8-hour average ozone exceeding $85 \mathrm{ppb}$ increases with temperature in both the

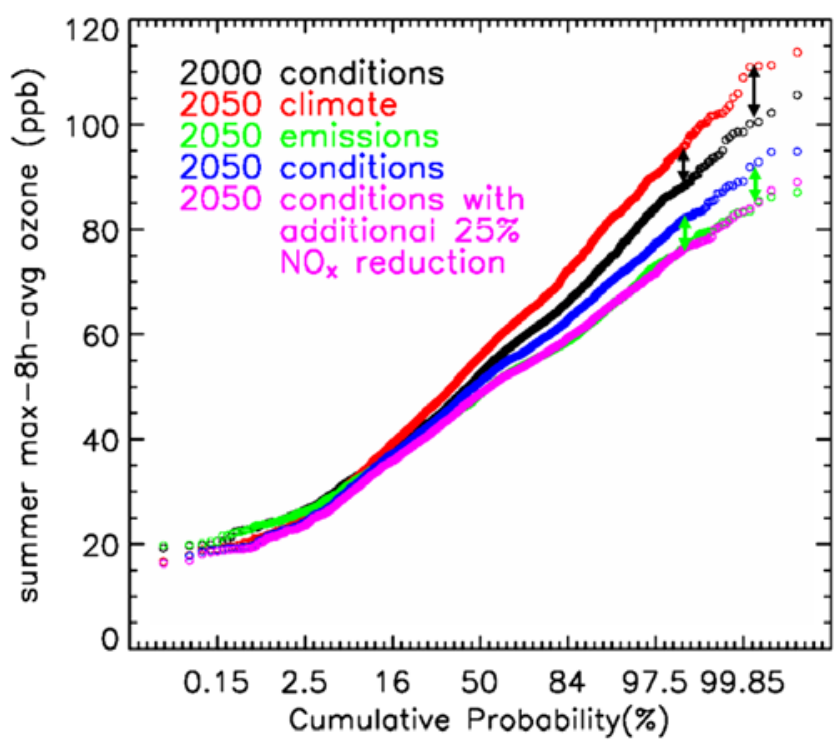

Figure 6. Simulated cumulative probability distributions of summer maximum 8-hour average surface ozone over the Midwest for 2000 climate and anthropogenic emissions (black circles); 2050 climate and 2000 anthropogenic emissions (red circles); 2000 climate and 2050 anthropogenic emissions (green circles); 2050 climate and anthropogenic emissions (blue circles); and 2050 climate and anthropogenic emissions but with $25 \%$ additional domestic $\mathrm{NO}_{\mathrm{x}}$ emission reductions (U.S. anthropogenic $\mathrm{NO}_{\mathrm{x}}$ emissions reduced by $50 \%$ instead of $40 \%$ compared to 2000 levels; pink circles that closely overlap the green circles). Each point on the curve represents a daily maximum 8-hour average ozone sampled from one of the 12 regional grid squares for three summers; thus each curve contains 3312 points. Results are plotted on a normal probability scale such that a normal probability distribution would be a straight line. The black and green arrows measure the climate change penalty for ozone air quality with 2000 and 2050 anthropogenic emissions, respectively. 


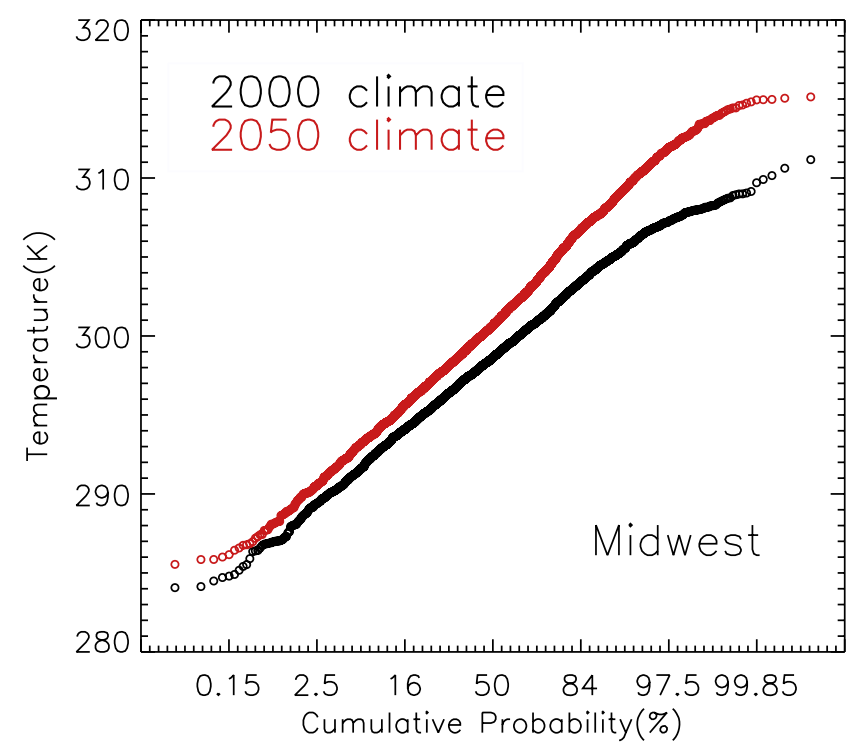

Figure 7. Cumulative probability distributions of summer daily maximum surface air temperature over the Midwest for the 2000 (black circles) and 2050 (red circles) climates, based on statistics for three model summers (2049-2051 versus 1999-2001).

southeast and the northeast, though the increase in the southeast is much weaker.

\subsection{Effect on Ozone Pollution Episodes}

[27] The previous GISS GCM study by Mickley et al. [2004] using pollution tracers found that the effect of 2000 2050 climate change on air quality in the northeast and Midwest was largest during pollution episodes (high tail of the probability distribution). We examine this effect here through the cumulative probability distributions of summer daily maximum 8-hour average ozone for three regions: Midwest, northeast, and southeast (geographical definition in Figure 5).

[28] Figure 6 shows the probability distributions of ozone over the Midwest for the base case (2000 conditions) and the three sensitivity simulations. Each curve in Figure 6 represents the ensemble of daily maximum 8-hour average surface ozone values for the three summers and for all grid squares in the region. We see that climate change has indeed the greatest effect on the high end of the distribution, corresponding to pollution events; the 95th percentile ozone increases by $10 \mathrm{ppb}$ by 2050 . Inspection of the cumulative probability distributions of temperature in the Midwest shows a similar effect, i.e., maximum change at the high end of the distribution representing heat waves (Figure 7). This likely reflects the increase in frequency of stagnation episodes [Mickley et al., 2004], with a positive feedback involving soil moisture that exacerbates the surface temperature increase through reduced evaporation [Schar et al., 2004]. In contrast, ozone in the midrange of the probability distribution has typically a strong influence from subsiding background air [Fiore et al., 2002b]. This background ozone is expected to decrease as a result of climate change [Johnson et al., 1999] which partly offsets the ozone increase.
[29] Figure 8 shows the same cumulative probability distributions for ozone as Figure 6 but for the northeast and southeast. Results for the northeast are similar to the Midwest, consistent with Mickley et al. [2004], as both regions would be similarly affected by the reduced frequency of midlatitude cyclones and associated frontal passages. By contrast, we find that ozone in the southeast is insensitive to climate change over the full extent of the probability distribution and actually shows the opposite relationship at the extreme high end. As discussed earlier, the increase of isoprene emissions over the southeast in our simulation actually tends to decrease ozone levels. Frontal passages are also less important in the southeast, where most of the summertime ventilation is by convection [Li et al., 2005].

[30] Our finding of the greatest sensitivity of ozone to climate change during pollution episodes is consistent with the previous model studies of Hogrefe et al. [2004] and Tagaris et al. [2007]. In contrast, Murazaki and Hess [2006] found the largest ozone increases at the low end of the probability distribution for their target region of the eastern and central United States. This discrepancy appears to be

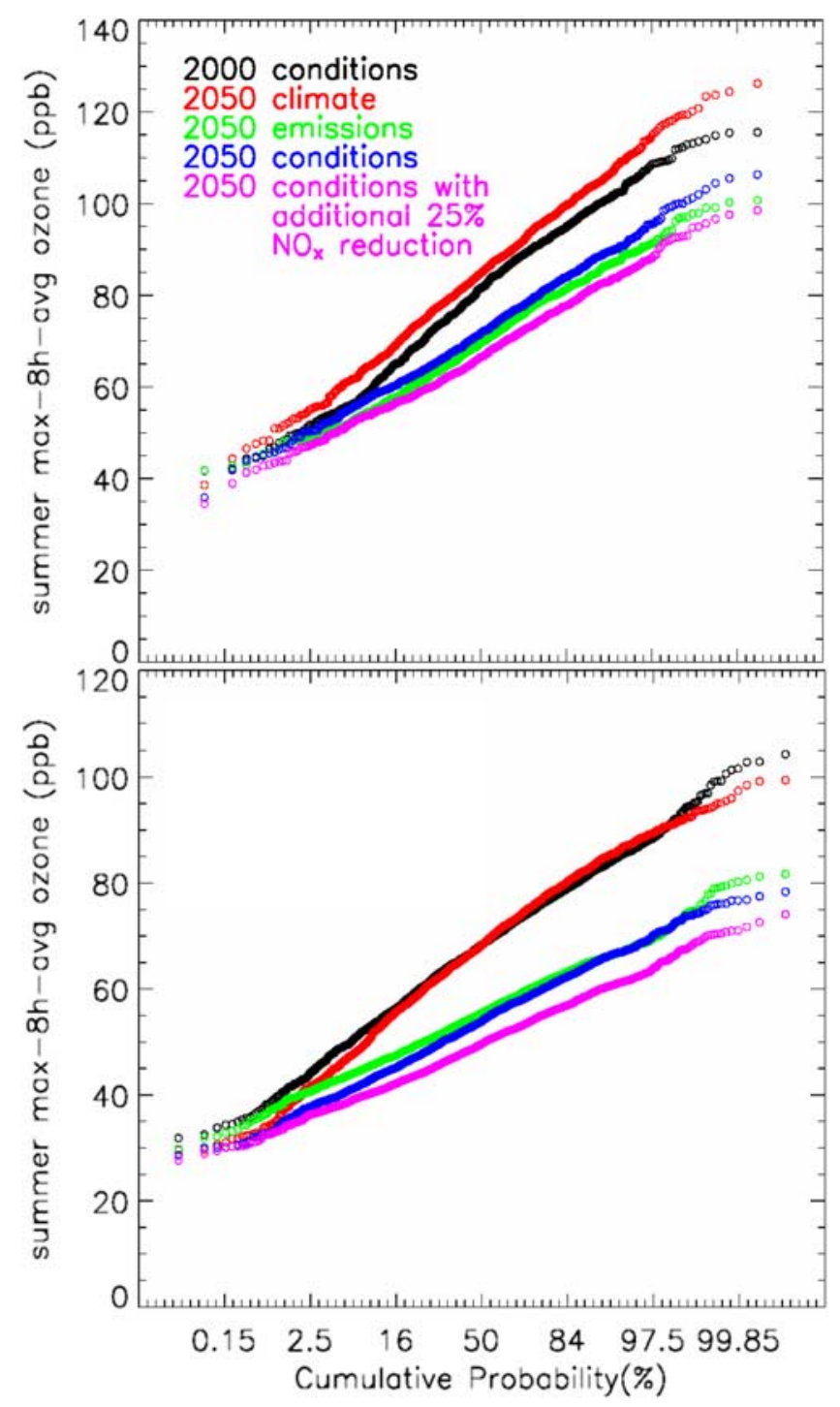

Figure 8. Same as Figure 6 but for the (top) northeast and (bottom) southeast. 

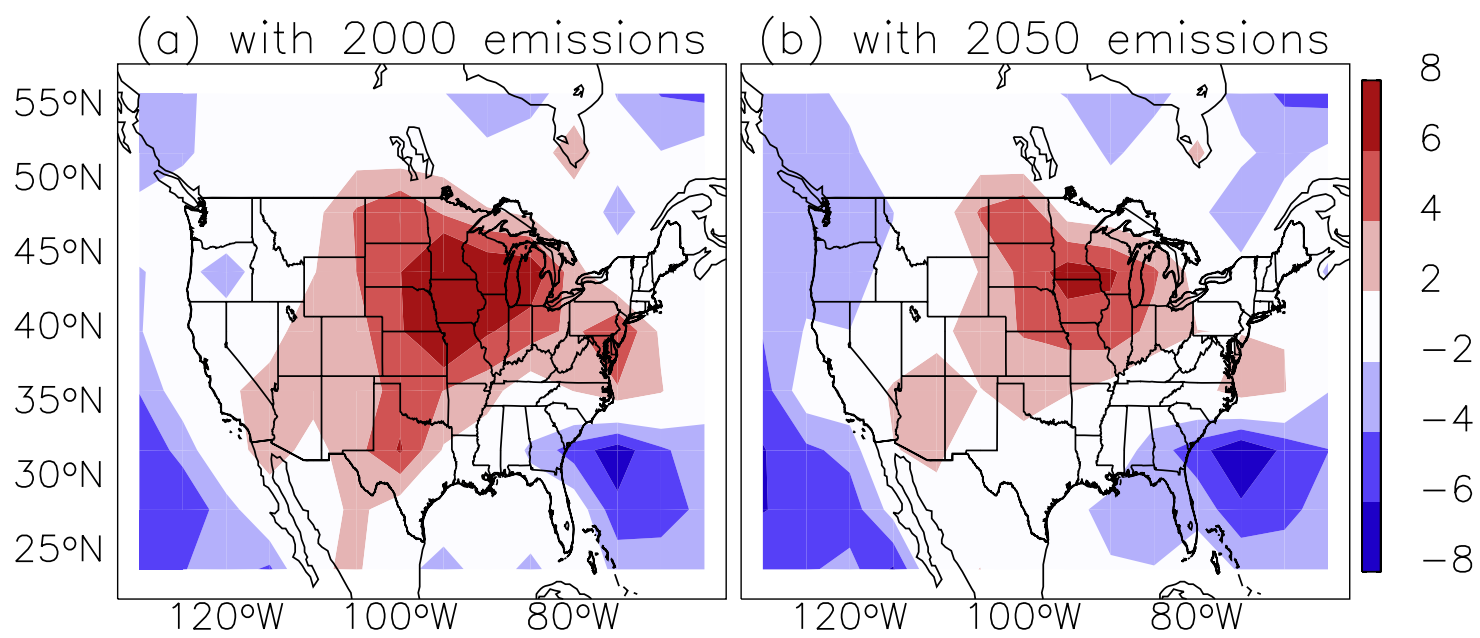

Figure 9. The 2000-2050 climate change penalty on ozone air quality. Shown are the climate-driven changes of summer 90th percentile maximum 8-hour average surface ozone (in ppb) with (a) 2000 and (b) 2050 anthropogenic emissions of ozone precursors.

partly due to the different statistics used. Murazaki and Hess [2006] did not include the spatial variation of ozone within their target region for constructing the probability distribution and instead sampled only the spatial maximum, median, and minimum. We reconstructed our ozone probability distributions using their method, and indeed also obtain a large effect in the midrange of the probability distribution; this appears however to reflect subsampling relative to the full distribution including spatial variation. We still find (with their method) negligible effect at the low end of the ozone distributions; their finding of a large effect seems difficult to reconcile with the robust result that background ozone should decrease in the future climate.

\section{The Climate Change Penalty and Implications for Emission Controls}

[31] The increase in surface ozone as a result of future climate change represents a "climate change penalty" because it offsets the benefits of emission controls to reduce ozone pollution, and it implies that more stringent emission controls will be required to meet a given ozone air quality target in the future. Figure 6 shows the climate change penalty in the Midwest, for 2000 and 2050 emissions (black and green arrows respectively). One can alternatively express the climate change penalty as the amount of additional $\mathrm{NO}_{\mathrm{x}}$ emission controls that will be required as a result of climate change to attain a given air quality target, considering that $\mathrm{NO}_{\mathrm{x}}$ is usually the limiting precursor for ozone formation.

[32] The A1B scenario assumes a $40 \%$ anthropogenic $\mathrm{NO}_{\mathrm{x}}$ emission reduction in the United States from 2000 to 2050 (Table 1a), representing projected emission control strategies to improve ozone air quality. We may assume that this reduction is intended to achieve a specific ozone target, guided by model simulations for the present-day climate. This target is represented by the green curve in Figure 6, which shows the effect of reducing $\mathrm{NO}_{\mathrm{x}}$ emissions for the present-day climate. However, climate change will cause the ozone air quality to improve less than desired (blue curve in Figure 6), so that additional emission controls will be required to meet the original ozone air quality target represented by the green curve.

[33] We quantified this additional emission control requirement owing to the climate change penalty by conducting additional sensitivity simulations for 2050 conditions (climate and anthropogenic emissions). As shown in Figure 6 , a $50 \%$ reduction in U.S. anthropogenic $\mathrm{NO}_{\mathrm{x}}$ emissions for the 2050 climate (pink curve) reproduces the ozone air quality target from the $40 \%$ reduction for the 2000 climate. The climate change penalty represents in this case $10 \%$ of present-day $\mathrm{NO}_{\mathrm{x}}$ emissions. If emission control strategies for 2000-2050 based on present-day climate call for a $40 \%$ decrease in U.S. $\mathrm{NO}_{\mathrm{x}}$ emissions, then our analysis indicates that $25 \%$ additional controls (i.e., a 50\% decrease in emissions) will be needed to compensate for the climate change penalty and meet the ozone air quality target in the Midwest.

[34] Figure 9 shows the geographical distribution of the 2000-2050 climate change penalty for 2000 and 2050 anthropogenic emissions, expressed as the change in the summer 90th percentile daily maximum 8-hour average ozone due to 2000-2050 climate change. The climate change penalty with 2050 emissions, as discussed above, is mostly in the Midwest with some effect also in the northeast. However, with 2000 emissions (i.e., without the projected $40 \%$ decrease in U.S. $\mathrm{NO}_{\mathrm{x}}$ emissions by 2050), the climate change penalty would be larger and extend over a broader area. The larger climate change penalty with 2000 anthropogenic emissions is also apparent from Figure 6 (black versus green arrows). This points to a significant co-benefit of reducing U.S. anthropogenic emissions, i.e., mitigating the climate change penalty or even turning it into a climate change benefit as in the southeast or the northwest (Figure 9). In the latter case, the changing climate actually enhances the effectiveness of emission controls.

[35] There are two reasons why domestic emission reductions act to mitigate the climate change penalty. First, the ozone background then makes a relatively larger contribu- 
tion to surface ozone and we have seen previously that climate change (higher water vapor) causes this background to decrease. The second is related to the effect from increasing isoprene with climate change. The lower $\mathrm{NO}_{\mathrm{x}}$ levels reduce the efficiency of ozone production from isoprene [Lin et al., 1988; Sillman et al., 1990; Kang et al., 2003] and hence lead to less increase (as occurs in the northeast) or further decrease (as occurs in the southeast) of ozone in response to the increasing isoprene.

\section{Conclusions}

[36] We investigated the effects of 2000-2050 global change on U.S. ozone air quality by using a global chemical transport model (GEOS-Chem CTM) with meteorological input from a general circulation model (GISS GCM 3). We considered separately and then together the effects of changes in climate and global anthropogenic emissions of ozone precursors based on the IPCC [2001] A1B scenario. Our focus was to determine the implications of climate change for meeting air quality goals in the United States. We find that surface ozone in remote areas decreases in the future climate owing to enhanced ozone destruction associated with increased humidity. As a result, the background surface ozone imported into the United States [Fiore et al., 2003a] is expected to decrease with climate change.

[37] The A1B scenario for 2000-2050 projects large decreases in U.S. anthropogenic emissions of ozone precursors $\left(40 \%\right.$ for $\left.\mathrm{NO}_{\mathrm{x}}\right)$ to improve air quality. We find that these decreases under 2000 climate conditions reduce the mean summer daily maximum 8 -hour average ozone by $2-5 \mathrm{ppb}$ in the western United States and 5-15 ppb in the east. On the other hand, we find that climate change increases the mean summer daily maximum 8-hour average ozone by $2-5 \mathrm{ppb}$ over large areas in the United States, with maximum effect over the Midwest. Little effect from climate change is found in the southeast.

[38] We examined the 2000-2050 trends in GCM air pollution meteorology to gain insight into the effects of climate change on U.S. surface ozone. The summertime surface temperature in the United States increases by $1-3{ }^{\circ} \mathrm{C}$, with the maximum warming in the south-central United States owing to northeastward shift of the Bermuda High. Mixing depths increase in the central United States but decrease in the northeast, reflecting changes in soil moisture. Convective ventilation generally decreases. The frequency of midlatitude cyclones and associated frontal passages is found to decrease, and this has particular impact in the Midwest and northeast where these frontal passages are a major ventilation mechanism.

[39] Increasing biogenic isoprene emission due to warmer temperatures in the 2050 climate contributes to increasing ozone in the northern United States but causes a decrease in the southeast. As a result, the latter region experiences little net impact of climate change on ozone air quality. Isoprene emissions in the southeast are particularly high, and $\mathrm{NO}_{\mathrm{x}}$ emissions are relatively low, so that increasing isoprene emission tends to reduce ozone levels through sequestration of $\mathrm{NO}_{\mathrm{x}}$ as isoprene nitrates and isoprene ozonolysis. This result is sensitive to the yield and fate of isoprene nitrates, both of which remain uncertain [Giacopelli et al., 2005; Horowitz et al., 2007]. In addition, it is unclear whether the assumed temperature dependence of isoprene emission (based on measurements of instantaneous response) applies to projecting emission in a warmer climate. Other effects such as changes in land cover and increasing $\mathrm{CO}_{2}$ [Rosenstiel et al., 2003; Centritto et al., 2004] would likely be more important in affecting isoprene emission but are not considered in our work.

[40] Through intercomparison with previous model studies, we find that the southeast is the region with the least consensus regarding the effects of climate change on ozone air quality. We speculate that this is driven at least in part by differences between models in the yield and fate of isoprene nitrates. There is better agreement between models in the northeast and Midwest; most find that these two regions are likely to experience substantial degradation of ozone air quality in the future climate.

[41] We find that ozone pollution episodes in the Midwest and the northeast are far more affected by climate change than the mean ozone levels. The 95th percentile ozone increases by up to $10 \mathrm{ppb}$ due to $2000-2050$ climate change. The same pattern is found for temperature; climate change has the greatest effect at the high end of the distribution (heat waves). This result is consistent with the previous work of Mickley et al. [2004] for air pollution tracers. It appears to be driven in part by the decreasing frequency of midlatitude cyclones [Mickley et al., 2004], and is amplified for ozone by (1) increased isoprene emission, (2) less efficient sequestration of $\mathrm{NO}_{\mathrm{x}}$ as PAN, and (3) reduced background influence during pollution episodes.

[42] The effect of climate change on surface ozone in the United States can be expressed as a "climate change penalty" for emission control strategies aiming to achieve a certain ozone air quality target. This means in particular that a $40 \%$ projected decrease in U.S. anthropogenic $\mathrm{NO}_{\mathrm{x}}$ emissions (as assumed in the A1B scenario) to meet an ozone air quality target assuming 2000 climate will fall short of this target in the Midwest and northeast (though not in the southeast), according to our model. We find in a sensitivity simulation that a reduction of up to $50 \%$ in U.S. $\mathrm{NO}_{\mathrm{x}}$ emissions is necessary under the 2050 climate to achieve the same ozone air quality in the Midwest and northeast as a $40 \%$ reduction under 2000 climate. The climate change penalty in this case can thus be expressed as an additional $10 \%$ decrease required in $\mathrm{NO}_{\mathrm{x}}$ emissions relative to 2000 levels. The penalty would be larger in the absence of $\mathrm{NO}_{\mathrm{x}}$ emission reductions; emission controls have the co-benefit of decreasing the climate change penalty, and even turning it into a climate benefit in the southeast and the northwest.

[43] Acknowledgments. This work was supported by the U.S. Environmental Protection Agency's STAR Program. We thank Arlene Fiore, NOAA Geophysical Fluid Dynamics Laboratory, for her help in processing AIRS ozone data and emission growth factors, and Jeff Jonas, NASA Goddard Institute for Space Studies for providing and supporting the storm tracking procedure.

\section{References}

Bey, I., D. J. Jacob, R. M. Yantosca, J. A. Logan, B. D. Field, A. M. Fiore, Q. Li, H. Y. Liu, L. J. Mickley, and M. G. Schultz (2001), Global modeling of tropospheric chemistry with assimilated meteorology: Model description and evaluation, J. Geophys. Res., 106, 23,073-23,095. 
Centritto, M., et al. (2004), Profiles of isoprene emission and photosynthetic parameters in hybrid poplars exposed to free-air $\mathrm{CO}_{2}$ enrichment, Plant Cell Environ., 27(4), 403-412, doi:10.1111/j.1365-3040.2003.01156.x.

Constable, J. H., A. B. Guenther, D. S. Schimel, and R. K. Monson (1999), Modeling changes in VOC emission in response to climate change in the continental United States, Global Change Biol., 5, 791-806.

Dawson, J. P., P. J. Adams, and S. N. Pandis (2007), Sensitivity of ozone to summertime climate in the eastern USA: A modeling case study, Atmos. Environ., 41, 1494-1511.

Del Genio, A. D., M.-S. Yao, and J. Jonas (2007), Will moist convection be stronger in a warmer climate?, Geophys. Res. Lett., 34, L16703, doi:10.1029/2007GL030525.

Dentener, F. D., D. S. Stevenson, J. Cofala, R. Mechler, M. Amann, P. Bergamaschi, F. Raes, and R. G. Derwent (2005), Tropospheric methane and ozone in the period 1990-2030: CTM calculations on the role of air pollutant and methane emissions controls, Atmos. Chem. Phys., 5, 1731-1755.

Fiore, A. M., D. J. Jacob, B. D. Field, D. G. Streets, S. D. Fernandes, and C. Jang (2002a), Linking ozone pollution and climate change: The case for controlling methane, Geophys. Res. Lett., 29(19), 1919, doi:10.1029/ 2002GL015601.

Fiore, A. M., D. J. Jacob, I. Bey, R. M. Yantosca, B. D. Field, A. C. Fusco, and J. G. Wilkinson (2002b), Background ozone over the United States in summer: Origin, trend, and contribution to pollution episodes, J. Geophys. Res., 107(D15), 4275, doi:10.1029/2001JD000982.

Fiore, A. M., D. J. Jacob, H. Liu, R. M. Yantosca, T. D. Fairlie, and Q. Li (2003a), Variability in surface ozone background over the United States: Implications for air quality policy, J. Geophys. Res., 108(D24), 4787, doi:10.1029/2003JD003855.

Fiore, A. M., D. J. Jacob, R. Mathur, and R. V. Martin (2003b), Application of empirical orthogonal functions to evaluate ozone simulations with regional and global models, J. Geophys. Res., 108(D14), 4431, doi:10.1029/2002JD003151.

Fiore, A. M., L. W. Horowitz, D. W. Purves, H. Levy II, M. J. Evans, Y. Wang, Q. Li, and R. M. Yantosca (2005), Evaluating the contribution of changes in isoprene emissions to surface ozone trends over the eastern United States, J. Geophys. Res., 110, D12303, doi:10.1029/ 2004JD005485.

Giacopelli, P., K. Ford, C. Espada, and P. B. Shepson (2005), Comparison of the measured and simulated isoprene nitrate distributions above a forest canopy, J. Geophys. Res., 110, D01304, doi:10.1029/2004JD005123.

Guenther, A., et al. (1995), A global model of natural volatile organic compound emissions, J. Geophys. Res., 100, 8873-8892.

Hansen, J., A. Lacis, D. Rind, G. Russell, P. Stone, I. Fung, R. Ruedy, and J. Lerner (1984), Climate sensitivity: Analysis of feedback mechanisms, in Climate Processes and Climate Sensitivity, Geophys. Monogr. Ser., vol. 29, edited by J. E. Hansen and T. Takahashi, pp. 130-163, AGU, Washington, D. C.

Hansen, J., I. Fung, A. Lacis, D. Rind, S. Lebedeff, R. Ruedy, and G. Russell (1988), Global climate changes as forecast by Goddard Institute for Space Studies three-dimensional model, J. Geophys. Res., 93, 9341-9364.

Hansen, J., et al. (2002), Climate forcings in Goddard Institute for Space Studies SI2000 simulations, J. Geophys. Res., 107(D18), 4347, doi:10.1029/2001JD001143.

Hogrefe, C., B. Lynn, K. Civerolo, J.-Y. Ku, J. Rosenthal, C. Rosenzweig, R. Goldberg, S. Gaffin, K. Knowlton, and P. L. Kinney (2004), Simulating changes in regional air pollution over the eastern United States due to changes in global and regional climate and emissions, J. Geophys. Res., 109, D22301, doi:10.1029/2004JD004690.

Holzer, M., and G. J. Boer (2001), Simulated changes in atmospheric transport climate, J. Clim., 14, 4398-4420.

Horowitz, L. W., A. M. Fiore, G. P. Milly, R. C. Cohen, A. Perring, P. J. Wooldridge, P. G. Hess, L. K. Emmons, and J.-F. Lamarque (2007), Observational constraints on the chemistry of isoprene nitrates over the eastern United States, J. Geophys. Res., 112, D12S08, doi:10.1029/ 2006JD007747.

Houghton, J. T., Y. Ding, D. J. Griggs, M. Noguer, P. J. van der Linden, X. Dai, K. Maskell, and C. A. Johnson (Eds.) (2001), Climate Change 2001: The Scientific Basis, 881 pp., Cambridge Univ. Press, New York.

Hudman, R. C., et al. (2004), Ozone production in transpacific Asian pollution plumes and implications for ozone air quality in California, J. Geophys. Res., 109, D23S10, doi:10.1029/2004JD004974.

Hudman, R. C., et al. (2007), Surface and lightning sources of nitrogen oxides over the United States: Magnitudes, chemical evolution, and outflow, J. Geophys. Res., 112, D12S05, doi:10.1029/2006JD007912.

Intergovernmental Panel on Climate Change (IPCC) (2001), Atmospheric chemistry and greenhouse gases, in Climate Change 2001: The Scientific Basis, edited by J. T. Houghton et al., pp. 239-288, Cambridge Univ. Press, New York.
Intergovernmental Panel on Climate Change (IPCC) (2007), Climate Change 2007: The Physical Science Basis, 996 pp., Cambridge Univ. Press, New York.

Jacob, D. J., J. A. Logan, G. M. Gardner, R. M. Yevich, C. M. Spivakovsky, and S. C. Wofsy (1993), Factors regulating ozone over the United States and its export to the global atmosphere, J. Geophys. Res., 98, $14,817-14,826$.

Jacob, D. J., J. A. Logan, and P. P. Murti (1999), Effect of rising Asian emissions on surface ozone in the United States, Geophys. Res. Lett., 26 , $2175-2178$

Johnson, C. E., W. J. Collins, D. S. Stevenson, and R. G. Derwent (1999), The relative roles of climate and emissions changes on future oxidan concentrations, J. Geophys. Res., 104, 18,631-18,645.

Kang, D., V. P. Aneja, R. Mathur, and J. D. Ray (2003), Nonmethane hydrocarbons and ozone in three rural southeast United States national parks: A model sensitivity analysis and comparison to measurements, J. Geophys. Res., 108(D19), 4604, doi:10.1029/2002JD003054.

Kunkel, K. E., H.-C. Huang, X.-Z. Liang, J.-T. Lin, D. Wuebbles, Z. Tao, A. Williams, M. Caughey, and J. Zhu (2007), Sensitivity of future ozone concentrations in the northeast U. S. to regional climate change, Mitigation Adaptation Strategies Global Change, 12, doi:10.1007/s11027-0079137-y.

Lambert, S. J., and J. C. Fyfe (2006), Changes in winter cyclone frequencies and strengths simulated in enhanced greenhouse warming experiments: Results from the models participating in the IPCC diagnostic exercise, Clim. Dyn., 26, 713-728.

Leung, L. R., and W. I. Gustafson Jr. (2005), Potential regional climate change and implications to U. S. air quality, Geophys. Res. Lett., 32, L16711, doi:10.1029/2005GL022911.

Li, Q. B., et al. (2002a), Transatlantic transport of pollution and its effects on surface ozone in Europe and North America, J. Geophys. Res., 107(D13), 4166, doi:10.1029/2001JD001422.

Li, Q. B., D. J. Jacob, T. D. Fairlie, H. Liu, R. M. Yantosca, and R. V. Martin (2002b), Stratospheric versus pollution influences on ozone at Bermuda: Reconciling past analyses, J. Geophys. Res., 107(D22), 4611, doi:10.1029/ 2002JD002138.

Li, Q. B., D. J. Jacob, J. W. Munger, R. M. Yantosca, and D. D. Parrish (2004), Export of $\mathrm{NO}_{y}$ from the North American boundary layer: Reconciling aircraft observations and global model budgets, J. Geophys. Res., 109, D02313, doi:10.1029/2003JD004086.

Li, Q., D. J. Jacob, R. Park, Y. Wang, C. L. Heald, R. Hudman, R. M. Yantosca, R. V. Martin, and M. Evans (2005), North American pollution outflow and the trapping of convectively lifted pollution by upper-level anticyclone, J. Geophys. Res., 110, D10301, doi:10.1029/ 2004JD005039.

Lin, C.-Y. C., D. J. Jacob, and A. M. Fiore (2001), Trends in exceedances of the ozone air quality standard in the continental United States, 1980-1998, Atmos. Environ., 35, 3217-3228.

Lin, X., M. Trainer, and S. C. Liu (1988), On the nonlinearity of the tropospheric ozone production, J. Geophys. Res., 93, 15,879-15,888.

Lu, J., G. A. Vecchi, and T. Reichler (2007), Expansion of the Hadley cell under global warming, Geophys. Res. Lett., 34, L06805, doi:10.1029/ 2006GL028443

Martin, R. V., et al. (2002), Interpretation of TOMS observations of tropical tropospheric ozone with a global model and in situ observations, J. Geophys. Res., 107(D18), 4351, doi:10.1029/2001JD001480.

McCabe, G. J., M. P. Clark, and M. C. Serreze (2001), Trends in Northern Hemisphere surface cyclone frequency and intensity, J. Clim., 14 $2763-2768$

McLinden, C. A., et al. (2000), Stratospheric ozone in 3-D models: A simple chemistry and the cross-tropopause flux, J. Geophys. Res., 105, 14,653-14,665.

Mickley, L. J., D. J. Jacob, B. D. Field, and D. Rind (2004), Effects of future climate change on regional air pollution episodes in the United States, Geophys. Res. Lett., 31, L24103, doi:10.1029/2004GL021216.

Murazaki, K., and P. Hess (2006), How does climate change contribute to surface ozone change over the United States?, J. Geophys. Res., 111, D05301, doi:10.1029/2005JD005873

Nakicenovic, N., and R. Swart (Eds.) (2000), Special Report on Emissions Scenarios, 570 pp., Cambridge Univ. Press, New York.

Park, R. J., D. J. Jacob, B. D. Field, R. M. Yantosca, and M. Chin (2004), Natural and transboundary pollution influences on sulfate-nitrateammonium aerosols in the United States: Implications for policy, J. Geophys. Res., 109, D15204, doi:10.1029/2003JD004473.

Pickering, K. E., Y. Wang, W. Tao, C. Price, and J. Müller (1998), Vertical distributions of lightning $\mathrm{NO}_{\mathrm{x}}$ for use in regional and global chemical transport models, J. Geophys. Res., 103, 31,203-31,216.

Price, C., and D. Rind (1992), A simple lightning parameterization for calculating global lightning distributions, J. Geophys. Res., 97, 9919-9933. 
Racherla, P. N., and P. J. Adams (2006), Sensitivity of global tropospheric ozone and fine particulate matter concentrations to climate change, J. Geophys. Res., 111, D24103, doi:10.1029/2005JD006939.

Rind, D. (1986), The dynamics of warm and cold climates, J. Atmos. Sci., $43,3-24$.

Rind, D., J. Lerner, and C. McLinden (2001), Changes of tracer distributions in the doubled $\mathrm{CO}_{2}$ climate, J. Geophys. Res., 106, 28,061-28,079.

Rind, D., J. Lerner, J. Jonas, and C. McLinden (2008), Effects of resolution and model physics on tracer transports in the NASA Goddard Institute for Space Studies general circulation models, J. Geophys. Res., 112, D09315, doi:10.1029/2006JD007476.

Rosenstiel, T. N., M. J. Potosnak, K. L. Griffin, R. Fall, and R. K. Monson (2003), Increased $\mathrm{CO}_{2}$ uncouples growth from isoprene emission in an agriforest ecosystem, Nature, 421(6920), 256-259.

Sanderson, M. G., C. D. Jones, W. J. Collins, C. E. Johnson, and R. G. Derwent (2003), Effect of climate change on isoprene emissions and surface ozone levels, Geophys. Res. Lett., 30(18), 1936, doi:10.1029/ 2003GL017642.

Sauvage, B., et al. (2007), Remote sensed and in situ constraints on processes affecting tropical tropospheric ozone, Atmos. Chem. Phys., 7, 815-838.

Schar, C., et al. (2004), The role of increasing temperature variability in European summer heatwaves, Nature, 427, 332-336.

Sillman, S., and P. J. Samson (1995), The impact of temperature on oxidant formation in urban, polluted rural and remote environments, J. Geophys. Res., 100, 11,497-11,508.

Sillman, S., J. A. Logan, and S. C. Wofsy (1990), The sensitivity of ozone to nitrogen oxides and hydrocarbons in regional ozone episodes, J. Geophys. Res., 95, 1837-1851.

Stevenson, D. S., R. M. Doherty, M. G. Sanderson, C. E. Johnson, W. J. Collins, and R. G. Derwent (2005), Impacts of climate change and variability on tropospheric ozone and its precursors, Faraday, 130 doi:10.1039/b417412g.
Stevenson, D. S., et al. (2006), Multimodel ensemble simulations of presentday and near-future tropospheric ozone, J. Geophys. Res., 111, D08301, doi:10.1029/2005JD006338.

Streets, D. G., T. C. Bond, T. Lee, and C. Jang (2004), On the future of carbonaceous aerosol emissions, J. Geophys. Res., 109, D24212, doi:10.1029/2004JD004902.

Tagaris, E., K. Manomaiphiboon, K.-J. Liao, L. R. Leung, J.-H. Woo, S. He, P. Amar, and A. G. Russell (2007), Impacts of global climate change and emissions on regional ozone and fine particulate matter concentrations over the United States, J. Geophys. Res., 112, D14312, doi:10.1029/ 2006JD008262.

Tao, Z., A. Williams, H.-C. Huang, M. Caughey, and X.-Z. Liang (2007), Sensitivity of U. S. surface ozone to future emissions and climate changes, Geophys. Res. Lett., 34, L08811, doi:10.1029/2007GL029455.

Wang, Y., D. J. Jacob, and J. A. Logan (1998), Global simulation of tropospheric $\mathrm{O}_{3}-\mathrm{NO}_{\mathrm{x}}$-hydrocarbon chemistry: 1.Model formulation, J. Geophys. Res., 103, 10,713-10,725.

Wu, S., L. J. Mickley, D. J. Jacob, J. A. Logan, R. M. Yantosca, and D. Rind (2007), Why are there large differences between models in global budgets of tropospheric ozone?, J. Geophys. Res., 112, D05302, doi:10.1029/ 2006JD007801.

D. J. Jacob, E. M. Leibensperger, L. J. Mickley, and S. Wu, School of Engineering and Applied Sciences, Harvard University, Pierce Hall, 20 Oxford St., Cambridge, MA 02138-2901, USA. (s.wu@post.harvard.edu)

D. Rind, NASA Goddard Institute for Space Studies, 2880 Broadway, New York, NY 10025, USA

D. G. Streets, Argonne National Laboratory, 9700 S. Cass Ave., Argonne, IL 60439, USA. 